\title{
Non-Dietary Analytical Features of Chimpanzee Scats
}

\section{Citation}

Phillips, Caroline, A. Richard Wrangham, and William McGrew. 2017. Non-dietary Analytical Features of Chimpanzee Scats. Primates 58, no. 3: 393-402.

\section{Permanent link}

http://nrs.harvard.edu/urn-3:HUL.InstRepos:41707596

\section{Terms of Use}

This article was downloaded from Harvard University's DASH repository, and is made available under the terms and conditions applicable to Open Access Policy Articles, as set forth at http:// nrs.harvard.edu/urn-3:HUL.InstRepos:dash.current.terms-of-use\#OAP

\section{Share Your Story}

The Harvard community has made this article openly available.

Please share how this access benefits you. Submit a story.

\section{Accessibility}


Title: Non-dietary analytical features of chimpanzee scats

Authors Caroline A Phillips1,2, Richard W Wrangham3, William C McGrew2,4

1. Present address: Evolutionary Studies Institute, University of the Witwatersrand, Private Bag 3, Wits 2050, South Africa.

2. Department of Archaeology and Anthropology, University of Cambridge, 13A Fitzwilliam Street, Cambridge, CB2 1QH, United Kingdom.

3. Department of Human Evolutionary Biology, Peabody Museum, Harvard University, 11 Divinity Avenue, Cambridge, MA 02138, USA.

4. School of Psychology \& Neuroscience, University of St. Andrews, St. Andrews,

KY16 9JU, Scotland

No. text pages plus references: 25 No. figures: $0 \quad$ No. tables: 2

Corresponding author: Caroline Phillips

Present postal address: Evolutionary Studies Institute, University of the Witwatersrand, Wits 2050, SOUTH AFRICA

Email: Caroline.Phillips@wits.ac.za

Tel: $+27(0) 117176682$

Keywords: Pan troglodytes, great ape, faeces, defaecation rate, body-weight, census 


\begin{abstract}
Non-dietary aspects of ape scats such as scat weight and diameter are correlated with age and sex of defecator for gorillas and orangutans. Defaecation rates of primates, including apes, illuminate their role as primary seed dispersers. We assess if non-dietary features of scats for East African chimpanzees (Pan troglodytes schweinfurthii) reveal such insights for members of the Kanyawara community in Kibale National Park, Uganda. Our objective is to see if such data yield useful perspectives for future census work on unhabituated chimpanzees, that is, what can scats tell us about a wild study population, beyond diet? We followed 10 adults from this community, as well as travelling parties, comparing observed vs. unobserved defaecations, and collected data on scat weight and dimensions, defaecation rate, scat encounter rate, and interval between defaecations. Few non-dietary features of chimpanzee scats significantly differentiated sex or age of the defecator, but total scat length and height distinguished adults from juveniles/infants. Defaecation rates and distance travelled were similar for adult males and females, indicating the importance of both sexes as potential primary seed dispersers. Observed travelling parties vs. non-observed travelling parties yielded similar data, indicating the potential to assess party size from scat encounter rates over a set distance. We provide detailed measurements
\end{abstract}


of scat dimensions for this ape taxon which previously have been lacking. This research builds upon prior work by recording more in-depth data for focal subjects and travelling parties on defaecation and scat encounter rates. The findings presented should assist in the interpretation of scat data when censusing unhabituated chimpanzees.

\section{Introduction}

Understanding population densities and species distribution is vital to initiate action plans for conserving wild primates. Such endeavours are achieved by completing census work across sites (surveying and monitoring the current status of remaining populations). Researchers face logistical challenges during census efforts when study subjects are wary to human observers at close proximity (i.e. unhabituated, Williamson and Feistner 2011). For primates, reconnaissance surveys are a common census technique, although the use of camera traps and mirrors can help to gain insight into animal behaviour (Boyer-Ontl and Pruetz 2014; Anderson et al. 2016). Surveys traversing large areas within home ranges determine: i) presence/absence of species in a region; ii) population density and distribution; and iii) behavioural ecology of unhabituated animals. Workers also seek indirect evidence, such as food remains, sleeping sites, foot or handprints, or scats, and opportunistic sightings and vocalisations of study subjects (Doran et al. 2002; Hernandez-Aguilar 2009; Williamson and Feistner 2011; Kalan et al. 2016). However, most 
primates remain unhabituated, and given ongoing threats to wildlife through habitat encroachment, zoonotic disease transfer, and hunting by humans (Travis et al. 2008; Linder and Oates 2011; Bezanson et al. 2013; Chaves et al. 2012; Rimbach et al. 2013), this approach will likely continue to be needed.

The following is a brief review of survey-related techniques that have been applied across primate taxa, especially in studies of great apes. Indirect evidence such as sleeping sites (usually arboreal), trails, feeding sites and remains, artefacts (e.g. used tools), knuckle-prints, footprints, hair and excreta have been used at many great ape study sites (McGrew et al. 1988; Tutin 1996; Rogers et al. 2004; Johnson et al. 2005; Koops 2011). Scats are commonly sought out to confirm ape presence, in particular, for sympatric gorillas (Gorilla spp.) and chimpanzees (Pan spp.) (Furuichi et al. 1997; Morgan et al. 2006; Sunderland Groves et al. 2003). Analyses of scat content has also proved helpful in understanding dietary and non-dietary aspects of great ape behaviour. At molecular level, genetic work on scats have increased our understanding of ape phylogenetics (Morin et al. 2001; Thalmann et al. 2007; Clifford et al. 2004; Chancellor et al. 2012), gene flow (Kanthaswamy and Smith 2002; Goosens et al. 2003) and paternity (Morin et al. 1994; Field et al. 1998; Constable et al. 2001; Inoue et al. 2013) as well as kinship, sex ratio, group size, and ranging (McGrew et al. 2004). Faecal glucocorticoid metabolites have detected stress responses in wild apes to social hierarchy and human encounters (Muehlenbein et al. 2012; Murray et al. 2013; Shutt et al. 2014) as well as reproductive cycles of females (Emery Thompson 2005). Stable isotope analysis of scats has provided insight into seasonality in great ape diet (Blumenthal et al. 2012; Phillips and O'Connell 2016) as well as infant weaning of apes (Bădescu et al. 2016). At the macroscopic level, scat consistency and presence of parasites 
have been used to indicate the health status and self-medication of study subjects (Wrangham 1995; Ashford et al. 2000; Krief et al. 2005) and inspection of scats has contributed greatly to understanding diet composition and seed dispersal across ape taxa (McGrew et al. 1988; Tutin and Fernandez 1993; Wrangham et al. 1994; Basabose 2002; Stanford and Nkuruningi 2003; Phillips and McGrew 2013, 2014). Thus, analysing scats may provide a wealth of data on great apes, but non-dietary features of scats have been little studied.

Most data for non-dietary analytical features concern either scat weight or defaecation rate (Williamson et al. 1990; Bradley et al. 2008; Takenoshita and Yamagiwa 2008; Todd et al. 2008). Weights of scats of mountain gorilla (Gorilla b. beringei), western lowland gorilla (G. g. gorilla) and Bornean orangutan (Pongo pygmaeus) correlate with defecator age and sex, with adults defecating heavier scats than juveniles and infants, and adult males producing heavier scats than females (Harcourt and Fossey 1981; Galdikas 1982; Tutin and Fernandez 1985).

Differences in bolus size (diameter) exist among adult male and female mountain and lowland gorillas, as well as among adults, juveniles and infants (Schaller 1963; Tutin and Fernandez 1993; McNeilage et al. 2006; McFarland 2007; Todd et al. 2008). Faecal bolus diameter also has been used to contrast scats of sympatric eastern chimpanzees (P. t. schweinfurthii) and eastern lowland gorillas (G. g. graueri) (Yamagiwa et al. 1996).

Measuring defaecation rate when combined with dietary analyses of scats has illuminated seed dispersal roles for all ape taxa (McConkey and Chivers, 2007 for gibbons (Hylobates meulleri x agilis); Wrangham et al. 1994, Gross-Camp et al. 2009 for chimpanzees; Tsuji et al. 2010 , Beaune et al. 2013 for bonobos (P. paniscus); Rogers et al. 1998, Voysey et al. 1999 for gorillas; Galdikas 1982 for orangutans), and for other 
frugivorous primates: Estrada and Coates-Estrada (1991) for howler monkeys, Alouatta palliata; Chapman (1995) for sympatric primates in Africa, Asia and South America; Lucas and Corlett (1998) for long-tailed macaques, Macaca fascicularis; Poulsen et al. (2001) for sympatric primates in Africa. Some tree species depend on primates as principal dispersers of their seeds, so knowledge of defaecation rate of study individuals, collected across seasons with seed content of scats and diurnal distance travelled, helps to reveal a primate's role in forest regeneration and conservation (Gross-Camp et al. 2009; Tsuji et al. 2010, Beaune et al. 2013).

Population densities also have been estimated through decay rate of great ape scats (Morgan et al. 2006; Morgan 2007), which may be a viable alternative to nest decay rates (Takenoshita and Yamagiwa 2008; Todd et al. 2008). Chimpanzee scats appear to decompose at a faster rate than gorilla scats, due to lower fibre content (Morgan et al. 2006). This raises the question as to whether they can also be used to estimate chimpanzee population densities (Takenoshita and Yamagiwa 2008). Measured decay rates of scats have not been published for any chimpanzee site, but data on decay and disappearance rates of scats for the Kanyawara community in Kibale National Park, Uganda, from June to December 2008, reveal a decomposition period of over $60 \mathrm{hr}$ for some scats in the dry season (Phillips et al. unpubl. data).

Chimpanzee scats can be distinguished from those of other sympatric primate species with relative ease due to size, form, odour, consistency, and associated traces (Tutin 1996; Poulsen et al. 2001; Basebose 2002; Morgan et al. 2006). However, no descriptive information and little non-dietary systematic measurements (i.e. scat dimensions and weight) are available. The lack of such data applies across fauna in general, and the logistical difficulties of observing study animals likely explains this paucity. For species that are mostly arboreal, locating and 
measuring of scats that have been scattered by understory vegetation on descent is taxing, but solutions are being found to locate primate scats, such as training dogs to do so (Orkin et al. 2016). Also, determining scat dimensions (i.e., diameter, length, width and height) and volume is difficult when scat consistency is less than solid. Nevertheless, non-dietary information provides insights into age, sex, health, and population density of apes.

We present findings from measuring non-dietary analytical features of scats from the habituated Kanyawara chimpanzee community in Kibale National Park, Uganda to see if it can contribute to future census work on unhabituated chimpanzees (e.g. to find out how accurately scats inform about age and sex of individuals).

\section{Methods}

\section{Study site and study population}

Habitat and seasonality at the study site, as well as background information on the Kanyawara chimpanzee community, are described in Phillips and McGrew (2013). The Kanyawara chimpanzees were categorised into the following age classes: infant 0-5 years; juveniles 5-8 years; adolescents 8-15 years; and adults 15 years and older. The Uganda Wildlife Authority and Uganda National Council for Science and Technology permitted data collection on the Kanyawara chimpanzee community and research adhered to ethical guidelines set by the Department of Archaeology and Anthropology, University of Cambridge.

\section{Data collection}


Most data presented come from scat samples collected $<20$ min post-defaecation from following 10 fully habituated adult chimpanzees (five males and five females) for up to three consecutive days each (focal sample: Martin and Bateson 2007). We obtained two focal samples for nine of the ten focal subjects for test and retest purposes. To be certain of defecator identity, we collected scat samples from unobserved defaecations only when the focal subject was travelling alone. For unobserved defaecations, an independent scat was defined as faecal matter (>50\% of total scat) within a circular area of $\sim 20 \mathrm{~cm}$ diameter. Faecal matter found outside this area was excluded from sample collection. We determined this criterion through preliminary calculations of total distance between each stool (a section of scats defecated) per scat $(\mathrm{N}=75)$ which gave a median value of $19 \mathrm{~cm}$ (range: 0-4.2 m, Table S1, Supplementary Information). Median distance between each stool per scat was $10 \mathrm{~cm}$ (range: 0-4.2 m); Kuehl et al. (2007) found the same for western lowland gorillas. For 58\% (N=109) of stools, minimum distance was zero as they were touching.

Defaecation rates for members of the Kanyawara community are given by: i) number of scats produced per individual per day by the observed focal subjects; ii) total number of scats observed to be defecated by all members of a party per follow; and iii) total number of scats not seen to be deposited that were encountered along a transect $(25 \mathrm{~m}$ wide) through an area recently $(<20 \mathrm{~min})$ traversed by members of the community. This approximates to an unobserved chimpanzee party (Todd et al. 2008). Following both party types and encountering scats in which the defaecation was seen vs. unseen allowed the validation of scats to provide information on party-size, age and sex of defecator. To consider the role of each sex as primary seed dispersers, we analysed content of scats collected from the 10 focal subjects at macroscopic level. 
We used percentage volume estimates of food remains in scats (i.e., its percentage [100\%] of the total volume of food-item content per sieve) to determine composition of frugivory, folivory and faunivory in the diet (Basabose 2002; Phillips and McGrew 2014) and seed content (using percentage estimate of total volume of fig and non-fig seeds, Table S2, Supplementary Information) for both males and females in this community (Wrangham et al. 1994).

We recorded for observed defaecations: i) defaecation time; ii) defecator sex and age class (adult, adolescent, juvenile and infant); iii) location (to the nearest trail or transect and by using GPS; iv) defaecation height (m) which was the distance between the platform used to defecate and where the scat landed (measured with a $5 \mathrm{~m}$ tape measure, but estimated for arboreal defaecations); v) defaecation platform to see if a sex preference existed in the nature of the platform used for terrestrial defaecations, that is, whether they perched - further specifying if on a root, log, broken branch, rock, soil mound- or were walking, or had stopped to defecate either standing or crouching, and for arboreal defaecations, whether the chimpanzee was nested or not; vi) number of stools per scat and distance between them (cm) using $5 \mathrm{~m}$ tape measure; and vii) scat dimension (i.e. length, width and height of stools ( $\mathrm{cm})$ ), using self-made callipers, consisting of a metal $20 \mathrm{~cm}$ ruler with a detachable, washable plastic strip fitted around the ruler, allowing it to be slid up or down. For any arboreal defaecations scattered upon descent, the area coverage (m2) was measured (when possible) using the $5 \mathrm{~m}$ measuring tape.

As focal subjects were sometimes unobservable, some defaecations must have been missed (Phillips and McGrew 2013). Other unobserved defaecations included some of those from their arboreal beds (i.e. nocturnal defaecations or before the start of a focal sample: Todd 
et al. 2008). To compensate for missed diurnal defaecations, we calculated defaecation rate per hour for the 10 adult chimpanzees based on dividing the total number of defaecations observed (OD) by the total time each individual was in view per daily focal sample (Tiv). We then used the 13-hr diurnal period (DP) to prorate defaecations for the 10 adult chimpanzees between un-nesting and nesting. This calculation for diurnal defaecation rate (DDR) throughout DP assumes defaecation rate was steady (Todd et al. 2008):

Diurnal defaecation rate $(\mathrm{DDR})=\underline{\mathrm{OD}}(\mathrm{DP})$

TIV

To determine defaecation rate by an observed party (total party size included chimpanzees of all ages), we followed 15 mixed-sex parties for $\leq 4 \mathrm{hr}$ (range: 00:46-03:58 h). Mean party size at the start of each follow was 12.5 \pm SE 13.9 individuals, but fission and fusion occurred during each follow. We followed each party ( $\geq 10 \mathrm{~m}$ behind) recording all observed defaecations in order to calculate: i) total scats encountered; ii) interval time per scat encounter; and iii) defaecation rate per hour. Finally, we recorded scats that were encountered (i.e. unobserved defaecations of a travelling party) whilst we traversed $\mathrm{a} \leq 3 \mathrm{~km}$ transect (range: $0.2-2.9 \mathrm{~km}$ ) which followed the direction travelled by 16 mixedsex parties (followed for $\leq$ 05:36 h; mean party size at beginning of follow: $10.8 \pm \mathrm{SE} 1.41$ ). We again recorded: $\mathrm{i}$ ) total scats encountered; and ii) interval time per scat encounter based on total scats encountered, to compare with follows of observed parties, to see how similar the data were for observable vs. unobservable defaecations for a party of chimpanzees. 
To determine scat weight (g), we first wet-weighed bagged samples of collected scats on a Kenex KX digital scale (400g x 0.1g capacity). We then deducted the average weight of 10 pre-weighed sample bags from the total weight of each bagged sample to calculate scat weight. To allow for any partial assemblages of scats we adjusted their wet-weights based on the estimated proportion (\%) of scat that had been collected, to approximate a 'complete' scat.

\section{Data analyses}

Samples sizes were small for statistical analyses, therefore, we used mean and median total repeated values for each individual rather than values for each focal sampling day to minimise pseudo-replication of data. Statistical analyses were done on MINITAB® Release 14 and SPSS version 21.0. The alpha value was set at 0.05 and normality of data was tested using the Anderson-Darling test.

For repeated measures from the 10 focal subjects, we used Mann Whitney U-tests (two-tailed) to compare sexes for observed defaecation rates per day and distance travelled per day. We applied Wilcoxon signed-rank tests to investigate seasonal changes in daily defaecation rates, using pooled values for focal subjects that were available in both wet and dry periods. We also tested for sex differences in defaecation interval time, defaecation rate per km and across a diurnal period (DP) using Student's t-tests (two-tailed). DP was based on the earliest and latest time observed for a chimpanzee to leave an overnight, arboreal bed (un-nest) and later to construct a new bed (nest). We also used this test for sex 
differences in scat seed content, and to compare percentage volume estimates of food remains in scats collected from both males and females. Paired t-tests (two-tailed) were used to compare diurnal variation for defaecation rates by sex across DP.

We applied Mann Whitney U-tests (two-tailed) to compare total scats encountered and interval between scat encounters for both observed and unobserved parties. We correlated total scats encountered vs. party-size and total time that parties were followed with Spearman Rank Correlation tests (homoscedasticity was confirmed by testing variance using ANOVA).

To assess sex differences in scat weight and scat dimensions, again Mann Whitney U-tests were done, and to compare scat weights across DP, which was divided into a 'morning/early afternoon' phase (06:15-12:29 hr, 'DPam') and an 'afternoon/evening' phase (13:00-19:15 hr, 'DPpm') Friedman tests were used. Student's t-tests (two-tailed) were applied to determine age-class differences in scat dimensions.

\section{Results}

\section{Defaecation rate}

During focal observations, we saw 335 defaecations by the 10 adults, plus 32 defaecations by seven adolescents, three juveniles and three infants $\left(n_{\text {adults }}=292 ; n_{\text {adolescents }}=21 ; n_{\text {juveniles }}=6\right.$; and $n$ infants $\left.=5\right)$. Median defaecation rate for the focal subjects was 6.4 day-1 per individual (range: 2.9-7.5 d-1). Defaecation rate did not differ by sex (ㅇ $6.7 \mathrm{~d}-1$; vs. $\stackrel{1}{0} 5.8 \mathrm{~d}$-1; Mann Whitney: W=34.5, $p=0.17, n=5$ females, 5 males). For adolescents, infants and juveniles, median defaecation rate was only one per day, presumably because of the challenge of observing their 
defaecations during focal adult follows. Thus, we give below non-dietary findings only for adult scats, except for scat dimensions for which all age-classes are included.

We found no seasonal difference in defaecation rates (Wilcoxon test: $\mathrm{T}=7.5, p=0.31, n=$ median defaecation rates per day from 7 adults; median $_{\text {wet }}=6.0 \mathrm{~d}-1$, mediandry $\left._{=}=6.0 \mathrm{~d}-1\right)$. Mean interval between observed adult defaecations was 01:59 h $(\widehat{\delta}=01: 41$, range: 00:02-04:11, $n=5$ individuals; $+=02: 18$, range: 00:02-10:35, $n=5$ individuals). We found no sex difference (Student's t-test: $\mathrm{T}=-1.31, p=0.25, n=5$ females, 5 males). No sex differences in defaecation rates across DP occurred either ( $+11.5 \mathrm{~d}-1$; §̊ $8.5 \mathrm{~d}-1$; T $=-2.42,=39, p=0.05, n=5$ males, 5 females). Across DP, defaecation rate for females was higher in the afternoon/evening phase (DPam: $2.6 \pm$ SE 0.4 vs. DPpm: $4.0 \pm$ SE 0.7; Paired t-test: $\mathrm{T}=-3.3, p<0.05, n=4)$; for males, no difference existed between the two phases $(\mathrm{T}=-1.07, p=0.36, n=4)$.

Per day, travel distance averaged $2.3 \pm$ SE $0.3 \mathrm{~km}$ for females (range: $0.5-4.9 \mathrm{~km}$ ) and $2.5 \pm$ SE $0.1 \mathrm{~km}$ for males (range: $1.3-4.4 \mathrm{~km}$ ) with no sex difference $(\mathrm{W}=23, p=0.40, n=5$ males, 5 females $)$.No sex difference occurred for defaecation rate per km $(Q=3.5 \mathrm{~km}-1 \mathrm{vs} . \hat{\jmath}=2.5 \mathrm{~km}$ 1; T=1.49, $p=0.18, n=5$ females, 5 males).

Mean percentage of food remains in scats $(n=112)$ analysed at macroscopic level showed no sex differences in frugivory, folivory, or faunivory (Table S2 and S3, Supplementary Information), or in scat seed content (Student's t-test: Non-fig seeds T=-0.13, $p=0.90, n=5$ males and 5 females: Fig-seeds $\mathrm{T}=-0.79, p=0.46$, Table S3, Supplementary Information). 
For observed defaecations of a known party size, the mean number of total scats was $5.8 \pm$ SE 0.9 per party (mean party size $12.5 \pm$ SE 13.9 individuals, range: $2-15$ ), median interval per scat encounter was $12 \mathrm{~min}$, and defaecation rate per hr was $3.3 \pm$ SE 0.5 . For scats encountered for the unobserved party, mean total was 7.1 \pm SE 1.7 scats per party (mean party size at beginning of follow: $10.8 \pm$ SE 1.41 , range: 0-26), median interval per scat encounter was $8 \mathrm{~min}$. We found no difference between party types (i.e. observed defaecations vs. unobserved defaecations) for total number of scats encountered or interval per scat encounter (Mann Whitney: total number scats: $\mathrm{W}=240.5, p=1.00, n=15$ and 16 parties followed; interval duration $\mathrm{W}=270, p=0.24)$. We found no correlation between total scats encountered and party-size (Spearman: $\left.\mathrm{r}_{\mathrm{s}}=0.21, p=0.45\right)$, or for total time a party was followed $\left(\mathrm{r}_{\mathrm{s}}=0.27, p=0.34\right)$.

\section{Scat weight}

Median scat weight for the 10 followed adults was $120 \mathrm{~g}$ (range: $14-288 \mathrm{~g}, n=198$ ). Not all scats could be collected due to: scat consistency (i.e. scats too loose to collect using a spatula or a plastic bag); risk of losing a focal subject who kept moving away during sample collection; and failure to locate all of the scat if displaced over a large area, especially from arboreal defaecations. Therefore, using our calculated 'complete' scat weights, scat weight did not differ between females (95g) and males (143g) (Mann Whitney: W=21, $p=0.21$; $q$ range: 14-288 g, N=105

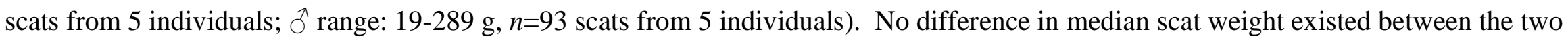
phases of DP for either sex (DPam: $\uparrow=111 \mathrm{~g} ; \hat{\jmath}=146 \mathrm{~g}$; DPpm: $q=107 \mathrm{~g} ; \hat{\jmath}=145 \mathrm{~g}$; Friedman: $\uparrow \mathrm{S}=1.8, p=0.18, n=5 ; \hat{ᄋ} \mathrm{~S}=0.2, p=0.66, n=5$ ).

[Tables 1 and 2 about here] 


\section{Scat dimensions}

Table 1 gives mean total scat length (calculated by adding up lengths of all stools per scat), stool length per scat, and stool width and height, each age class. For defaecations from different platforms, Table 2 gives scat dimensions for adult males and females. Median scat length did not differ between the sexes $(q=11.6 \mathrm{~cm}$, range: $4.1-23 \mathrm{~cm}, n=50$ scats from 5 individuals; $\hat{\jmath}=13.7 \mathrm{~cm}$, range: $5-24.1 \mathrm{~cm}, n=47 \mathrm{scats}$ from 5 individuals; Mann Whitney: $\mathrm{W}=20, p=0.14, n=5)$. We found no sex difference for stool length per scat $\left(q=6.2 \mathrm{~cm}\right.$ vs. $\oint^{\lambda}=8.2 \mathrm{~cm} ; \mathrm{W}=35, p$ $=0.14, n=5)$, nor for scat width and height $(\mathrm{W}=29.5, \mathrm{P}=0.75, n=5$ for width; $\mathrm{W}=26, p=0.83$ for height, $n=10$ individuals; scat width $9=4.8 \mathrm{~cm}$, range: $1.2-11 \mathrm{~cm}, n=50 ; \hat{\jmath}=5.2 \mathrm{~cm}$, range: $2.5-12.7 \mathrm{~cm}, n=47$; scat height $Q=3.1 \mathrm{~cm}$, range: $0.7-12.7 \mathrm{~cm}, n=50 ; \hat{\delta}=3.4 \mathrm{~cm}$, range: $0.8-8.6 \mathrm{~cm}$, $n=50)$. Between age classes, total scat length differed between adults $v s$. juveniles/infants, and adolescents $v s$. juveniles/infants $(p<0.05$ : Table 1). Scat height was greater for adults $v s$. juveniles/infants and stool length was longer for adolescents $v s$. juveniles/infants $(p<0.05$ : Table 1).

Both adult males and females defecated on average two stools per scat $(\propto \overline{\mathrm{x}}=2$ per scat; $\mathrm{N}=316$ stools; $\hat{\jmath} \overline{\mathrm{x}}=2.1 \pm \mathrm{SE} 0.3$ per scat; $n=262$ stools; range: 1-4 stools for both sexes) with a median total stool distance of $18 \mathrm{~cm}$ per scat (range: 0-2 m). For arboreal defaecations, most could not be found or collected, as they hit vegetation on descent and scattered. Of samples that could be measured, defaecation area for females was $\bar{x}$ $=1.1 \mathrm{~m} 2(1.03 \times 1.03 \mathrm{~m}, n=10$ scats $)$ and for males $\overline{\mathrm{x}}=0.4 \mathrm{~m} 2(0.63 \times 0.63 \mathrm{~m}, n=8$ scats $)$. Defaecation heights ranged from $4.5-12 \mathrm{~m}$. Sex difference could not be tested statistically (only $\leq 3$ individuals per sex available).

\section{Defaecation platform}


Of 286 adult defaecations seen, most (55\%) were terrestrial: $30 \%$ entailed perching (on: a fallen log (18\%) root (8\%), broken branch (2\%), soil mound, rock or vine (2\%)). The remaining defaecations occurred when an individual walked or stood quadrupedally (12\%), crouched, or was already lying down (13\%). Females defecated more often from trees ( $\overline{\mathrm{x}}=60 \%$ per female, $n=5$ adults) than terrestrially, and males more often on the ground, in particular on perches $(\overline{\mathrm{x}}=33 \%$ on $\log ; \overline{\mathrm{x}}=36 \%$ on root per male, $n=5$ adults $)$ or crouched $(\overline{\mathrm{x}}=37 \%)$.

\section{Discussion}

Unlike other great apes, there seem to be few non-dietary analytical features that distinguish scat differences between the sexes in adult chimpanzees. Scat weights were similar for males and females in this study, but they differ between male and female Bornean orangutans and western gorillas (Galdikas 1982; Tutin and Fernandez 1985). A more pronounced contrast in body mass between male and female Gorilla $(q=71.0 \mathrm{~kg}$ vs. $\hat{\delta}=175.2 \mathrm{~kg})$ and Pongo $(q=35.6 \mathrm{~kg}$ vs. $\hat{\delta}=78.5 \mathrm{~kg})$ compared to $P a n(q=33.7 \mathrm{~kg}$ vs. $\hat{\delta}=59.7 \mathrm{~kg})$ may explain sex differences in scat weight and scat dimension (Smith and Jungers 1997; Remis 2000). For diet composition (i.e. frugivory, folivory and faunivory intake) differences were also found between sexes for both gorillas and orangutans (Remis 2000 for western gorillas, Doran-Sheehy et al. 2009; Galdikas 1988 for Bornean orangutans), which could further explain the contrasting scat weights. Using percentage volume estimates of food remains in scats to determine diet composition, as applied in some of the above-cited studies, we found no difference in diet between the focal male and female chimpanzees, or in total number of plant foods eaten per day (Phillips 2012), total time spent feeding, total number of feeding 
bouts per day, or total bouts during morning vs. afternoon/evening feeding times (Phillips and McGrew 2014) that could influence scat content and weight.

Previous work on this community and the neighbouring Ngogo community revealed lower scat weights (range: 50-120g), although this difference was explained by incomplete sample collection from arboreal defaecations (Wrangham et al. 1994). For other chimpanzee communities, scat weights were also lower; 65.7g in the Dja Reserve, Cameroon (Poulsen et al. 2001), and 100g in Nyungwe National Park, Rwanda (Gross-Camp et al. 2009). Our use of an estimation for 'complete' scat weight probably explains our heavier sample weights.

Scat dimensions did not differ between Kanyawara males and females. However, for census work, measuring total scat length or scat height may assist in differentiating ages of defecators, particularly between adults and juveniles/infants. Our dimensions, provided across the age groups, may also help to recognise chimpanzee scats when compared with sympatric primates. Few published data on wild chimpanzee scat measurements are available. Yamagiwa et al. (1996) at Kahuzi-Biega National Park, Zaire, found scat diameters to be for infants $<3 \mathrm{~cm}$, juveniles $3-5 \mathrm{~cm}$, adolescent and adults $>4 \mathrm{~cm}$. These resemble our width and height values for these age classes (Table 1). As previously mentioned, bolus diameter is used for gorillas to establish sex or age of defecator, with silverbacks producing largest scats (Yamagiwa et al. 1996; Todd et al. 2008), but as scats measured in this study were not tubular, diameter was not a useful measure. Lambert (2002) gave mean scat length of $10 \mathrm{~cm}$ and width of $3.8 \mathrm{~cm}$ for scats from two captive adult chimpanzees, which is smaller than that for Kanyawara adults $(\sim 12-14 \mathrm{~cm}$ 
scat length $v s . \sim 5 \mathrm{~cm}$ for scat width). This size difference could be due to many factors, such as differences in diet, diurnal activity rates, climate, or environmental surroundings.

Primates' role as primary seed dispersers for some tree species is usually determined from defaecation rate and content of scats.

Estimated defaecation rate for the Kanyawara chimpanzees over a 12-h period was 6.7 d-1 per individual, based on recording a defaecation interval length of 01:48 $\mathrm{h}$ (Wrangham et al. 1994). Our estimate over the same period was higher, at $9.4 \mathrm{~d}-1$ per individual (range: $4.2-12.8 \mathrm{~d}-1$ ), but our interval length was similar at 01:59 h. Similar rates were found for adult bonobos at Lui Kotale, Democratic Republic of Congo at 7.6 d-1 and 01:35 h (Beaune et al. 2013). Lack of sex difference between our observed male and female defaecation rates (except that females defecate more in the latter part of the day), or their defaecation interval time (as in the bonobo study above), indicates that both sexes are equally 'effective' seed dispersers (Beaune et al. 2013). The focal adults in this study traversed similar distances per day and had similar percentage volume contents of seeds in their scats. Using a larger sample size, Pontzer and Wrangham (2006) found males traversed a greater distance than females for this community ( $\widehat{\delta} 2.4 \mathrm{~km} \mathrm{~d}-1$ vs. $q \sim 1.9 \mathrm{~km} \mathrm{~d}-1$ ). Therefore, some bias between sexes within Kanyawara, such as core areas utilised by adult females and males, and the locations of these core areas (Kahlenberg et al. 2008; Bertolani 2013) may influence seed dispersal. Although defaecation platform data agree with previous observations that most defaecations occurred terrestrially (Wrangham et al. 1994), females produced more arboreal defaecations than males. This may reflect the well-known female inclination across great apes to greater 
arboreality (Doran 1996); females followed in this study spent more time feeding in trees and males more at ground level (Phillips and O'Connell 2016).

Given no statistical differences between observed and unobserved parties for the total number of scats encountered or the interval between scat encounters, finding scats left by travelling parties of unhabituated chimpanzees could be a useful proxy for party-size. We found total scats encountered were $\sim 7$ for a travelling party of 10-12 individuals, up to a $3 \mathrm{~km}$ distance. However, with no correlation between partysize and time followed for total scats encountered, the inference of providing a proxy for party-size remains unproven.

Information on non-dietary features from chimpanzee scats is attainable and provides insights into defecator age, based on total scat length and height measurements, along with a general estimate of party size over a set distance using defaecation encounter rates. However, compared to scats from gorillas and orangutans, such data do not reveal sex of defecator. Our findings are constrained by small sample sizes for most ageclasses, and other factors such as the softer consistency of chimpanzee scats than gorilla scats may affect scat shape on defaecation for both sexes. Pan are less sexually dimorphic in body-size than Gorilla gorilla (Remis 2000), which may simply explain the similarity in non-dietary scat features between adult male and female chimpanzees.

This study provides the first in-depth overview of non-dietary analytical features of scats of $P$. t. schweinfurthii, and therefore may assist in the collection and interpretation of scat samples during census work on unhabituated chimpanzees. For example, we suggest that future studies use a maximum area of $20 \mathrm{~cm}$ diameter (located around the largest part of each scat) to differentiate between scats of individual chimpanzees. 
Acknowledgments Research funding was awarded by the Board of Graduate Studies of the University of Cambridge, Murray Edwards College,

Ridgeway-Venn Travel Fund, Sir Richard Stapely Education Trust, and Leverhulme Trust. Long-term work at Kanyawara was supported by the U.S. National Science Foundation (grants 9807448, 0416125, and 1355014), the Leakey Foundation, the National Geographic Society, the Getty Foundation and the Wenner-Gren Foundation for Anthropological Research. All applicable international, national, and institutional guidelines for the care and use of animals were followed. All procedures performed in studies involving animals were in accordance with the ethical standards of the institution or practice at which the studies were conducted. Permission to live and conduct research in Kibale National Park, Uganda, was given by the Uganda Wildlife Authority, Uganda Council for Science and Technology, Makerere University Biological Field Station, Martin Muller and Emily Otali of the Kibale Chimpanzee Project. The authors thank all staff of the Kibale Chimpanzee Project for their assistance during sample collection.

\section{References}

Anderson JR, Hubert-Brierre X, McGrew WC (2016) Reflections in the rainforest: full-length mirrors facilitate behavioral observations of unhabituated, wild chimpanzees. Primates doi:10.1007/s10329-016-0574-7

Ashford RW, Reid GD, Wrangham RW (2000) Intestinal parasites of the chimpanzee Pan troglodytes in Kibale Forest, Uganda. Ann Trop Med Parasitol 94:173-179

Bădescu I, Katzenberg MA, Watts DP, Sellen DW (2016) A novel fecal stable isotope approach to determine the timing of age-related feeding transitions in wild infant chimpanzees. Am J Primatol doi: 10.1002/ajpa.23116 
Basabose, AK (2002) Diet composition of chimpanzees inhabiting the montane forest of Kahuzi, Democratic Republic of Congo. Am J Primatol 58:1-21

Beaune D, Bretagnolle F, Bollache L, Hohmann G, Surbeck M, Fruth B (2013) Seed dispersal strategies and the threat of defaunation in a Congo forest. Biodivers Conserv 22:225-238

Bertolani MP. 2013. Ranging and travelling patterns of wild chimpanzees at Kibale: a GIS approach. PhD thesis, University of Cambridge, Cambridge

Bezanson M, Stowe R, Watts SM (2013) Reducing the ecological impact of field research. Am J Primatol 75:1-9

Blumenthal S, Chritz K, Rothman J, Cerling T (2012) Detecting

intra-annual dietary variability in wild mountain gorillas by stable isotope

analysis of feces. Proc Natl Acad Sci USA109:21277-21282

Boyer-Ontl KM, Pruetz JD (2014) Giving the forest eyes: The benefits of using camera traps to study unhabituated chimpanzees (Pan troglodytes verus) in southeastern Senegal. Int J Primatol doi: 10.1007/s10764-014-9783-3

Bradley BJ, Doran-Sheehy DM, Vigliant L (2008) Genetic identification of elusive animals: re-evaluating tracking and nesting data for wild western gorillas. J Zool 275: 333-340

Chancellor RL, Langergraber Ramirez S, Rundus AS, Vigilant L (2012) Genetic sampling of unhabituated chimpanzees (Pan troglodytes schweinfurthii) in Gishwati Forest Reserve, an isolated forest fragment in western Rwanda. Int J Primatol doi: 10.1007/s 10764-012-9591-6

Chapman CA (1995) Primate seed dispersal: Coevolution and conservation implications. Evol Anthropol 4:74-82

Chaves OM, Stoner KE, Arroyo-Rodríguez V (2012) Differences in diet between spider monkey groups living in forest fragments and continuous forest in Mexico. Biotropica 44:105-113 
Clifford SL, Anthony NM, Bawe-Johnson M, Abernethy KA, Tutin CE, White LJ, Bermejo M, Goldsmith ML, McFarland K, Jeffery KJ, Bruford MW (2004) Mitochondrial DNA phylogeography of western lowland gorillas (Gorilla gorilla gorilla). Mole Ecol 13:1551-1565

Constable JL, Ashley MV, Goodall J, Pusey AE (2001) Noninvasive paternity assignment in Gombe chimpanzees. Mole Ecol 10:1279-1300

Doran DM (1996) Comparative positional behavior of the African apes. In: McGrew WC, Marchant LF, Nishida T (eds) Great ape societies. Cambridge University Press, Cambridge, pp 213-224

Doran DM, McNeilage A, Greer D, Bocian C, Mehlman P, Shah N (2002) Western lowland gorilla diet and resource availability: New evidence, cross-site comparisons, and reflections on indirect sampling methods. Am J Primatol 58:91-116

Doran-Sheehy D, Mongo P, Lodwick J, Conklin-Brittain NL (2009) Male and female western gorilla diet: preferred foods, use of fallback resources, and implications for ape versus old world monkey foraging strategies. Am J Phys Anthropol 140:727-738

Emery Thompson M (2005) Reproductive endocrinology of wild female chimpanzees (Pan troglodytes schweinfurthii): methodological considerations and the role of hormones in sex and conception. Am J Primatol 67: 137-158

Estrada A, Coates-Estrada R (1991) Howler monkeys (Alouatta palliata), dung beetles (Scarabaeidae) and seed dispersal: ecological interactions in the tropical rain forest of Los Tuxtlas, Mexico. J Trop Ecol 7:459-474

Field D, Chemnick L, Robbins M, Garner K, Ryder O. (1998) Paternity determination in captive lowland gorillas and orangutans and wild mountain gorillas by microsatellite analysis. Primates 39:199-209

Furuichi T, Inagaki H, Anggoue-Ovono S (1997) Population density of chimpanzees and gorillas in the Petit Loango Reserve, Gabon: employing a new method to distinguish between nests of the two species. Int J Primatol 18: 1029-1046

Galdikas BM (1982) Orang utans as seed dispersers at Tanjung Puting, Central Kalimantan: implications for conservation. In: de Boer LEM (ed) The orang utan: its biology and conservation. Dr W Junk, The Hague, pp 285-298

Galdikas BMF (1988) Orangutan diet, range, and activity at Tanjung Puting, Central Borneo. Int J Primatol doi:10.1007/BF02740195 
Goosens B, Anthony N, Jeffery K, Johnson-Bawe M, Bruford MW (2003) Collection, storage and analysis of non-invasive genetic material in primate biology. In: Setchell JM, Curtis DJ (eds.) Field and laboratory methods in primatology. A practical guide Cambridge University Press, Cambridge, pp 295-308

Gross-Camp ND, Masozera M, Kaplin BA (2009) Chimpanzee seed dispersal quantity in a tropical montane forest of Rwanda. Am J Primatol 71:1-11

Harcourt AH, Fossey D (1981) The Virunga gorillas: decline of an 'island' population. Afr J Ecol 19:83-97

Hernandez-Aguilar RA (2009) Chimpanzee nest distribution and site reuse in a dry habitat: implications for early hominin ranging. J Hum Evol $57: 350-364$

Inoue E, Akomo-Okoue EF, Ando C, Iwata Y, Judai M, Fujita S, Hongo S, Nze-Nkogue C, Inoue-Murayama M, Yamagiwa J (2013) Male genetic structure and paternity in western lowland gorillas (Gorilla gorilla gorilla). Am J Phys Anthropol 151:583-588

Johnson AE, Knott CD, Pamungkas B, Pasaribu M, Marshall AJ (2005) A survey of the orangutan (Pongo pygmaeus wurmbii) population in and around Gunung Palung National Park, West Kalimantan, Indonesia based on nest counts. Biol Conserv 121:495-507

Kahlenberg SM, Emery Thompson M, Wrangham RW (2008) Female competition over core areas in Pan troglodytes schweinfurthii, Kibale National Park, Uganda. Int J Primatol doi:10.1007/s10764-008-9276-3

Kalan AK, Piel AK, Mundry R, Wittig RM, Boesch C, Kühl HS (2016) Passive acoustic monitoring reveals group ranging and territory use: a case study of wild chimpanzees (Pan troglodytes). Front Zool 13:34

Kanthaswamy S, Smith DG (2002) Population subdivision and gene flow among wild orangutans. Primates 43:315-327

Koops K. Chimpanzees in the Seringbara region of the Nimba Mountains (2011) In: Matsuzawa T, Hulme T, Sugiyama Y (eds.) The chimpanzees of Bossou and Nimba Springer, Tokyo, pp 277-287 
Krief S, Huffman MA, Sévenet T, Guillot J, Bories C, Hladik CM, Wrangham RW (2005) Noninvasive monitoring of the health of Pan troglodytes schweinfurthii in the Kibale National Park, Uganda. Int J Primatol 26:467-490

Kuehl HS, Todd A, Boesch C, Walsh PD (2007) Manipulating decay time for efficient large-mammal density estimation: gorillas and dung height. Ecol Appl 17:2403-2414

Lambert JE (2002) Exploring the link between animal frugivory and plant strategies: the case of primate fruit processing and post-dispersal seed fate. In: Levey D, Silva W, Galetti M (eds.) Seed dispersal and frugivory: ecology, evolution and conservation. CAB International, Wallingford, UK, pp 369-375

Linder JM, Oates JF (2011) Differential impact of bushmeat hunting on monkey species and implications for primate conservation in Korup National Park, Cameroon. Biol Conserv 144:738-74.

Lucas PW, Corlett RT (1998) Seed dispersal by long-tailed macaques. Am J Primatol 45:29-44

Martin P, Bateson P (2007) Measuring behaviour. An introductory guide. 3rdedit. Cambridge University Press, Cambridge

McConkey KR, Chivers DJ (2007) Influence of gibbon ranging patterns on seed dispersal distance and deposition site in a Bornean forest. J Trop Ecol 23:269-275

McFarland KL (2007) Ecology of Cross River gorillas (Gorilla gorilla diehli) on Afi Mountain, Cross River State, Nigeria. PhD, City University of New York

McGrew WC, Baldwin PJ, Tutin CEG (1988) Diet of wild chimpanzees (Pan troglodytes verus) at Mt. Assirik, Senegal: I. Composition. Am J Primatol 16:213-226

McGrew WC, Ensminger AL, Marchant LF, Pruetz JD, Vigilant L (2004) Genotyping aids field study of unhabituated wild chimpanzees. Am J Primatol 63:87-93 
McNeilage A, Robbins MM, Gray M, Olupot W, Babaasa D, Bitariho R, Kasangaki A, Rainer H, Asuma S, Mugiri G, Baker J (2006) Census of the mountain gorilla Gorilla beringei beringei population in Bwindi Impenetrable National Park, Uganda. Oryx 40:419-427

Morgan BJ (2007) Group size, density and biomass of large mammals in the Réserve de Faune du Petit Loango, Gabon. Afr J Ecol 45:508-518

Morgan D, Sanz C, Onononga JR, Strindberg S (2006) Ape abundance and habitat use in the Goualougo Triangle, Republic of Congo. Int J Primatol 27:147-179

Morin PA, Wallis J, Moore JJ, Woodruff DS (1994) Paternity exclusion in a community of wild chimpanzees using hypervariable simple sequence repeats. Mol Ecol 3:469-478

Morin PA, Chambers KE, Boesch C, Vigilant L (2001) Quantitative polymerase chain reaction analysis of DNA from non-invasive samples for accurate microsatelite genotyping of wild chimpanzees (Pan troglodytes verus). Mole Ecol 10:1835-1844

Muehlenbein MP, Ancrenaz M, Sakong R, Ambu L, Prall S, Fuller G, Raghanti MA (2012) Ape conservation physiology: fecal glucocorticoid responses in wild Pongo

pygmaeus morio following human visitation. PLoS ONE doi: 10.1371/journal.pone.0033357

Murray CM, Heintz MR, Lonsdorf EV, Parr LA, Santymire RM (2013) Validation of a field technique and characterization of fecal glucocorticoid metabolite analysis in wild chimpanzees (Pan troglodytes). Am J Primatol 75:57-64

Orkin JD, Yang Y, Yang C, Yu DW, Jiang X (2016) Cost-effective scat-detection dogs: unleashing a powerful new tool for international mammalian conservation biology. Sci Rep doi: 10.1038/srep34758

Phillips CA (2012) Chimpanzee diet: analyses at macroscopic, microscopic and molecular level. PhD thesis, University of Cambridge, Cambridge

Phillips CA, McGrew WC (2013) Identifying species in chimpanzee (Pan troglodytes) faeces: a methodological lost cause? Int J Primatol 34:792-807 
Phillips CA, McGrew WC (2014) Macroscopic inspection of ape feces: what's in a quantification method? Am J Primatol 76:539-550

Phillips CA, O’Connell T (2016) Fecal carbon and nitrogen isotopic analysis as an indicator of diet in Kanyawara chimpanzees, Kibale National Park, Uganda. Am J Phys Anthropol 161: 685-697.

Pontzer H, Wrangham RW (2006) Ontogeny of ranging in wild chimpanzees. Int J Primatol 27:295-309

Poulsen JP, Clark CJ, Smith TB (2001) Seed dispersal by a diurnal primate community in the Dja Reserve, Cameroon. J Trop Ecol 17:787-808

Remis MJ (2000) Initial studies on the contributions of body size and gastrointestinal passage rates to dietary flexibility among gorillas. Am J Phys Anthropol 112:171-180

Rimbach R, Link A, Heistermann M, Gómez-Posada C, Galvis N, Heymann EW (2013) Effects of logging, hunting, and forest fragment size on physiological stress levels of two sympatric ateline primates in Colombia. Conserv Physiol 1:1-11

Rogers ME, Abernethy K, Bermejo M, Cipolletta C, Doran D, McFarland K, Nishihara T, Remis M, Tutin CEG (2004) Western gorilla diet: a synthesis from six sites. Am J Primatol 64:173-192

Rogers ME, Voysey BC, McDonald KE, Parnell RJ, Tutin CEG (1998) Lowland gorillas and seed dispersal: the importance of nest sites. Am J Primatol 45:45-68

Schaller GB (1963) The mountain gorilla: ecology and behavior. University of Chicago Press, Chicago

Shutt K, Heistermann M, Kasim A, Todd A, Kalousova B, Profosouva I, Petrzelkova K, Fuh T, Dicky JF, Bopalanzognako JB, Setchell JM (2014) Effects of habituation, research and ecotourism on faecal glucocorticoid metabolites in wild western lowland gorillas: implications for conservation management. Biol Conserv 172:72-79

Smith RJ, Jungers WL (1997) Body mass in comparative primatology. J Hum Evol 32: 523-59 
Stanford CB, Nkurunungi JB (2003) Behavioral ecology of sympatric chimpanzees and gorillas in Bwindi Impenetrable National Park, Uganda: Diet. Int J Primatol 24:901-919

Sunderland-Groves JL, Maisels F, Ekinde A (2003) Surveys of the Cross River gorilla and chimpanzee populations in Takamanda Forest Reserve, Cameroon. In: Comiskey JA, Sunderland TCH, Sunderland-Groves JL (eds.) Takamanda: the biodiversity of an African rainforest. Smithsonian Institution Press, Washington DC, pp 129-140

Takenoshita Y, Yamagiwa J (2008) Estimating gorilla abundance by dung count in the northern part of Moukalaba-Doudou National Park, Gabon. Afr Study Monog 39:41-54

Thalmann O, Fischer A, Lankester F, Pääbo S, Vigilant L (2007) The complex evolutionary history of gorillas: insights from genomic data. Mole Biol Evol 24:146-158

Todd AF, Kuehl HS, Cipolletta C, Walsh PD (2008) Using dung to estimate gorilla density: modelling dung production rate. Intl J Primatol 29:549-563

Travis DA, Lonsdorf EV, Mlengeya T,Raphael J (2008) A science-based approach to managing disease risks for ape conservation. Am J Primatol 70:745-750

Tsuji Y, Yangozene K, Sakamaki T (2010) Estimation of seed dispersal distance by the bonobo, Pan paniscus, in a tropical forest in Democratic Republic of Congo. J Trop Ecol 26:115-118

Tutin CEG (1996) Ranging and social structure of lowland gorillas in the Lopé Reserve, Gabon. In: McGrew WC, Marchant LF, Nishida T (eds.) Great ape societies. Cambridge University Press, Cambridge, pp 58-70

Tutin CEG, Fernandez M (1985) Foods consumed by sympatric populations of Gorilla g. gorilla and Pan t. troglodytes in Gabon: some preliminary data. Int J Primatol 6:27-43

Tutin CEG, Fernandez M (1993) Faecal analysis as a method of describing diets of apes: examples from sympatric gorillas and chimpanzees at Lopé, Gabon. Tropics 2: 189-197 
Voysey BC, McDonald KE, Rogers ME, Tutin CEG, Parnell R (1999) Gorillas and seed dispersal in the Lopé Reserve, Gabon. I: gorilla acquisition by trees. J Trop Ecol 15:23-38

Williamson EA, Feistner ATC (2011) Habituating primates: processes,

techniques, variables and ethics. In: Setchell J, Curtis DJ (eds.) Field and laboratory methods in primatology: a practical guide. Cambridge University Press, Cambridge,

pp. 25-39

Williamson EA, Tutin CEG, Rogers ME, Fernandez M (1990) Composition of the diet of lowland gorillas at Lopé in Gabon. Am J Primatol $21: 265-277$

Wrangham RW (1995) Relationship of chimpanzee leaf-swallowing to a tapeworm infection. Am J Primatol 37: 297-304

Wrangham RW, Chapman CA, Chapman LJ (1994) Seed dispersal by forest chimpanzees in Uganda. J Trop Ecol 10:355-368

Yamagiwa J, Maruhashi T, Yumoto T, Mwanza N (1996) Dietary and ranging overlap in sympatric gorillas and chimpanzees in Kahuzi-Biega

National Park, Zaire. McGrew WC, Marchant LF, Nishida T (eds.) Great ape societies. Cambridge University Press, Cambridge, pp 82-98 
Table 1 Mean ( \pm SE) and range [cm] of scat dimensions: total scat length; stool length, width and height per scat for adults, adolescents, juveniles and infants of the Kanyawara chimpanzee community, Kibale National Park, Uganda.

\begin{tabular}{|c|c|c|c|c|}
\hline $\begin{array}{l}\text { Age class } \\
\text { (no. of subjects) }\end{array}$ & $\begin{array}{l}\text { Total scat } \\
\text { length }\end{array}$ & Stool length & Stool width & Stool height \\
\hline Adults $(\mathrm{N}=10)$ & $\begin{array}{c}13.7 \pm 0.9 \\
10.1 \text { to } 18.0\end{array}$ & $\begin{array}{l}7.8 \pm 0.4 \\
5.5 \text { to } 9.5\end{array}$ & $\begin{array}{l}5.2 \pm 0.2 \\
4.4 \text { to } 6.2\end{array}$ & $\begin{array}{l}3.2 \pm 0.2 \\
2.0 \text { to } 3.9\end{array}$ \\
\hline Adolescents $(\mathrm{N}=7)$ & $\begin{array}{l}12.7 \pm 1.1 \\
8.0 \text { to } 16.0\end{array}$ & $\begin{array}{l}7.1 \pm 0.7 \\
4.4 \text { to } 9.1\end{array}$ & $\begin{array}{l}4.7 \pm 0.60 \\
3.1 \text { to } 7.5\end{array}$ & $\begin{array}{l}1.9 \pm 0.47 \\
0.4 \text { to } 3.6\end{array}$ \\
\hline Juveniles (N=3) & $\begin{array}{c}8.8 \pm 1.2 \\
6.6 \text { to } 10.9\end{array}$ & $\begin{array}{c}6.6 \pm 2.3 \\
3.3 \text { to } 10.9\end{array}$ & $\begin{array}{l}5.3 \pm 1.1 \\
3.9 \text { to } 7.5\end{array}$ & $\begin{array}{l}1.6 \pm 0.8 \\
0.5 \text { to } 3.1\end{array}$ \\
\hline Infants $(\mathrm{N}=3)$ & $\begin{array}{l}5.3 \pm 1.2 \\
3.0 \text { to } 6.6\end{array}$ & $\begin{array}{l}5.3 \pm 1.2 \\
3.0 \text { to } 6.6\end{array}$ & $\begin{array}{l}3.8 \pm 0.2 \\
3.0 \text { to } 5.0\end{array}$ & $\begin{array}{l}1.4 \pm 0.6 \\
0.4 \text { to } 2.6\end{array}$ \\
\hline \multicolumn{5}{|c|}{ Dimensions compared by age-classes (Student's t-test) } \\
\hline Adults vs. adolescents & $\begin{array}{l}p=0.48 \\
\mathrm{~T}=0.73\end{array}$ & $\begin{array}{l}p=0.44 \\
\mathrm{~T}=0.81\end{array}$ & $\begin{array}{l}p=0.50 \\
\mathrm{~T}=0.71\end{array}$ & $\begin{array}{l}p=0.94 \\
\mathrm{~T}=-0.07\end{array}$ \\
\hline $\begin{array}{l}\text { Adults } v s \text {. } \\
\text { juveniles/infants }\end{array}$ & $\begin{array}{l}p<0.05 \\
\mathrm{~T}=4.74\end{array}$ & $\begin{array}{l}p=0.19 \\
\mathrm{~T}=1.47\end{array}$ & $\begin{array}{l}p=0.44 \\
\mathrm{~T}=0.83\end{array}$ & $\begin{array}{l}p<0.05 \\
\mathrm{~T}=2.58\end{array}$ \\
\hline
\end{tabular}


Adolescents $v s$.

$p<0.05$

$p<0.05$

$p=0.89$

$\mathrm{T}=0.14$

$p=0.57$

$\mathrm{T}=-0.59$

juveniles/infants

$\mathrm{T}=3.43$ 
Table 2 Mean percentage ( \pm SE) of defecations for each platform, from pooled mean totals for five adult female and five adult male chimpanzees of the Kanyawara community, Kibale National Park, Uganda. Mean defecation height $(\mathrm{m})$ by sex listed for defecation platforms. Total scat length [L], mean stool width $[\mathrm{W}]$ and height $[\mathrm{H}]$ from pooled mean total for all 10 chimpanzees. Number of defecations measured $[\mathrm{N}=90]$.

\begin{tabular}{|c|c|c|c|c|c|c|c|}
\hline platform & & $(\%)$ & $\begin{array}{c}\text { height } \\
\text { m }\end{array}$ & $\mathbf{N}$ & $\mathbf{L}$ & W & H \\
\hline \multirow[t]{2}{*}{ Tree } & o & 28.2 & $9.6 \pm 5.50$ & 5 & $9.9 \pm 4.2$ & $5.7 \pm 2.3$ & $1.2 \pm 0.6$ \\
\hline & o & 59.6 & $8.9 \pm 2.90$ & 20 & $11.6 \pm 4.0$ & $5.3 \pm 1.5$ & $2.5 \pm 1.0$ \\
\hline \multirow[t]{2}{*}{ Bed (day and night) } & $\hat{0}$ & 12.9 & $8.7 \pm 3.00$ & - & - & - & - \\
\hline & q & 1.9 & $8.0 \pm 7.50$ & - & - & - & - \\
\hline \multirow[t]{2}{*}{ Perch log } & $\hat{o}$ & 33.2 & $0.3 \pm 0.1$ & 14 & $14.3 \pm 4.5$ & $4.8 \pm 1.3$ & $4.2 \pm 1.7$ \\
\hline & q & 19.3 & $0.3 \pm 0.1$ & 16 & $5.3 \pm 3.8$ & $4.5 \pm 1.5$ & $3.8 \pm .2 .0$ \\
\hline \multirow[t]{2}{*}{ Perch broken branch } & $\hat{0}$ & 10.0 & 0.2 & - & - & - & - \\
\hline & $q$ & 11.1 & 0.5 & - & - & - & - \\
\hline \multirow[t]{2}{*}{ Perch root } & $\hat{\sigma}$ & 35.7 & $0.1 \pm 0.01$ & 8 & $13.6 \pm 2.9$ & $4.9 \pm 1.3$ & $4.9 \pm 1.6$ \\
\hline & $q$ & 4.1 & 0.1 & - & - & - & - \\
\hline \multirow{2}{*}{$\begin{array}{l}\text { Perch other } \\
\text { (e.g. rock) }\end{array}$} & 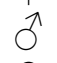 & 12.2 & $0.7 \pm 2.70$ & - & - & - & - \\
\hline & $q$ & 5.2 & 5.1 & - & - & - & - \\
\hline \multirow[t]{2}{*}{ Walk or stand } & $\hat{\sigma}$ & 25.9 & $0.5 \pm 0.10$ & 6 & $9.9 \pm 4.2$ & $4.9 \pm 1.2$ & $2.9 \pm 0.6$ \\
\hline & $q$ & 17.8 & $0.4 \pm 0.02$ & 7 & $7.5 \pm 6.5$ & $4.2 \pm 0.9$ & $2.9 \pm 1.4$ \\
\hline \multirow[t]{2}{*}{ Crouch } & 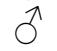 & 37.0 & $0.1 \pm 0.02$ & 11 & $14.5 \pm 4.5$ & $5.9 \pm 1.0$ & $3.6 \pm 1.0$ \\
\hline & $q$ & 11.6 & $0.1 \pm 0.05$ & 3 & $9.1 \pm 7.3$ & $4.9 \pm 4.3$ & $4.1 \pm 3.0$ \\
\hline
\end{tabular}


Table S1 Stool distance and number of stools per scat $(\mathrm{N}=75)$ used to calculate area of scat to collect to represent an independent sample. Total (average and median) stool distance per scat and median distance between stools per scat (m) provided. Data collected in Kanyawara, Kibale National Park, Uganda, between June and December 2008.

\begin{tabular}{|c|c|c|}
\hline Sample & Stool distance [m] & Number of stools per scat \\
\hline 1 & $2.00,2.12$ & 3 \\
\hline 2 & $1.5,0.00$ & 3 \\
\hline 3 & 2.00 & 2 \\
\hline 4 & 1.00 & 1 (stool split in two on descent) \\
\hline 5 & 0.58 & 2 \\
\hline 6 & 0.00 & 3 \\
\hline 7 & 0.00 & 2 \\
\hline 8 & 0.01 & 2 \\
\hline 9 & $0.02,0.60$ & 3 \\
\hline 10 & $0.00,0.06$ & 3 \\
\hline 11 & $0.00,0.00,0.02$ & 4 \\
\hline 12 & $0.18,0.05$ & 2 \\
\hline 13 & 0.50 & 2 \\
\hline 14 & 0.01 & 2 \\
\hline 15 & 0.00 & 2 \\
\hline 16 & $0.00,0.00,0.33$ & 4 \\
\hline 17 & $0.00,0.00,0.00$ & 4 \\
\hline 18 & $0.00,0.10$ & 3 \\
\hline 19 & 0.01 & 2 \\
\hline 20 & $2.20,0.00$ & 3 \\
\hline 21 & $0.04,0.17,0.15$ & $\begin{array}{c}2 \text { (one stool split in two on } \\
\text { descent) }\end{array}$ \\
\hline 22 & 0.16 & 2 \\
\hline 23 & $0.20,0.50,0.40$ & $\begin{array}{c}3 \text { (one stool split in two on } \\
\text { descent) }\end{array}$ \\
\hline 24 & 0.20 & 2 \\
\hline 25 & $0.00,0.67$ & 3 \\
\hline
\end{tabular}




\begin{tabular}{|c|c|c|}
\hline 26 & 0.00 & 2 \\
\hline 27 & 0.30 & 2 \\
\hline 28 & $0.10,0.13$ & 3 \\
\hline 29 & $0.08,0.10$ & 2 \\
\hline 30 & $0.00,0.05$ & 3 \\
\hline 31 & $0.05,0.00$ & 3 \\
\hline 32 & $0.12,0.27$ & 1 (stool split in two on descent) \\
\hline 33 & $0.00,0.00$ & 3 \\
\hline 34 & $0.00,0.00,0.00$ & 4 \\
\hline 35 & 0.00 & 2 \\
\hline 36 & 1.50 & 2 \\
\hline 37 & $0.67,0.00$ & 3 \\
\hline 38 & $0.10,0.09$ & 3 \\
\hline 39 & $0.06,0.02$ & 3 \\
\hline 40 & $0.32,0.36,0.00$ & 4 \\
\hline 41 & $0.30,0.17$ & 3 \\
\hline 42 & 0.38 & 2 \\
\hline 43 & 0.83 & 2 \\
\hline 44 & $0.05,0.04$ & 3 \\
\hline 45 & $0.05,0.08,0.03$ & 4 \\
\hline 46 & $0.04,0.09$ & $\begin{array}{c}2 \text { (one stool split in two on } \\
\text { descent) }\end{array}$ \\
\hline 47 & 4.20 & 2 \\
\hline 48 & $0.79,1.70$ & 3 \\
\hline 49 & $0.05,0.14,0.34$ & $\begin{array}{c}2 \text { (one stool split in two on } \\
\text { descent) }\end{array}$ \\
\hline 50 & 0.09 & 2 \\
\hline 51 & $0.20,0.04$ & 3 \\
\hline 52 & $0.11,0.00$ & 3 \\
\hline 53 & $0.75,0.15$ & 3 \\
\hline 54 & $0.50,0.16,0.00$ & 4 \\
\hline
\end{tabular}




\begin{tabular}{|c|c|c|}
\hline 55 & 0.19 & 2 \\
\hline 56 & 0.35 & 2 \\
\hline 57 & $0.00,0.00$ & 3 \\
\hline 58 & 0.00 & 2 \\
\hline 59 & 0.50 & 2 \\
\hline 60 & 0.00 & 2 \\
\hline 61 & 0.38 & 2 \\
\hline 62 & 1.70 & 2 \\
\hline 63 & 0.13 & 2 \\
\hline 64 & 0.11 & 2 \\
\hline 65 & 0.00 & 2 \\
\hline 66 & 0.00 & 2 \\
\hline 67 & 0.06 & 2 \\
\hline 68 & 0.00 & 2 \\
\hline 69 & 0.10 & 2 \\
\hline 70 & 0.07 & 2 \\
\hline 71 & $0.80,0.30$ & 3 \\
\hline 72 & 0.40 & 2 \\
\hline 73 & 0.50 & 2 \\
\hline 74 & 0.00 & 2 \\
\hline 75 & $0.06,0.00,0.05$ & 3 \\
\hline \multicolumn{2}{|c|}{ Total number of stools } & 187 \\
\hline \multicolumn{2}{|c|}{ Mean number of stools per scat } & $2.5 \pm$ SE 0.1 \\
\hline \multicolumn{2}{|c|}{ Total measurements of stool distance } & 116 \\
\hline \multicolumn{2}{|c|}{ Sum of stool distance of all scats [m] } & 37.1 \\
\hline \multicolumn{2}{|c|}{ Total stool distance per scat $=37.1 / 187[\mathrm{~m}]$} & 0.20 \\
\hline \multirow{2}{*}{\multicolumn{2}{|c|}{$\begin{array}{l}\text { Median total stool distance per scat [m] } \\
\text { Median distance between stools per scat [m] }\end{array}$}} & 0.19 \\
\hline & & 0.10 \\
\hline
\end{tabular}


Table S2 Percentage volume estimates (\%) of food-items found in faecal samples ( $N=112)$ collected from 10 adult chimpanzees. Total \% for three categories: frugivory, folivory and faunivory (shaded grey). Data collected in Kibale National Park, Uganda, between June and December 2008. Data adapted from Phillips and McGrew (2013).

\begin{tabular}{|c|c|c|c|c|c|c|c|c|c|c|c|c|}
\hline $\begin{array}{l}\text { Total } \\
\text { sample }\end{array}$ & $\begin{array}{l}\text { Focal } \\
\text { subject }\end{array}$ & $\begin{array}{l}\text { Fruit } \\
\text { seed }\end{array}$ & $\begin{array}{l}\text { Ficus } \\
\text { seed }\end{array}$ & $\begin{array}{l}\text { Whole } \\
\text { fruit }\end{array}$ & $\begin{array}{l}\text { Fruit } \\
\text { skin/flesh }\end{array}$ & FRUGIVORY & Fibre & Leaf & FOLIVORY & Invertebrate & $\begin{array}{l}\text { Red } \\
\text { colobus }\end{array}$ & FAUNIVORY \\
\hline 1 & MS & 34.0 & 0.0 & 0.0 & 0.0 & 34.0 & 48.3 & 1.0 & 49.3 & 0.0 & 0.0 & 0.0 \\
\hline 2 & LR & 42.5 & 0.0 & 0.0 & 50.0 & 92.5 & 0.0 & 5.0 & 5.0 & 0.0 & 0.0 & 0.0 \\
\hline 3 & WL & 1.3 & 20.0 & 0.3 & 16.7 & 38.3 & 25.0 & 1.7 & 26.7 & 0.0 & 0.0 & 0.0 \\
\hline 4 & YG & 26.7 & 28.3 & 0.0 & 5.0 & 60.0 & 33.3 & 3.3 & 36.7 & 0.0 & 0.0 & 0.0 \\
\hline 5 & LR & 23.3 & 16.7 & 0.0 & 0.0 & 40.0 & 50.0 & 0.0 & 50.0 & 0.0 & 10.0 & 10.0 \\
\hline 6 & MS & 28.3 & 30.0 & 0.0 & 21.7 & 80.0 & 0.0 & 0.0 & 0.0 & 0.0 & 20.0 & 20.0 \\
\hline 7 & MS & 23.3 & 25.0 & 1.7 & 13.3 & 63.3 & 28.0 & 1.7 & 29.7 & 0.3 & 0.0 & 0.3 \\
\hline 8 & MS & 33.3 & 15.0 & 2.7 & 18.3 & 69.3 & 24.0 & 6.7 & 30.7 & 0.0 & 0.0 & 0.0 \\
\hline 9 & MS & 5.0 & 10.0 & 0.1 & 8.3 & 23.4 & 48.7 & 27.6 & 76.3 & 0.2 & 0.0 & 0.2 \\
\hline 10 & MS & 20.0 & 25.0 & 1.7 & 5.0 & 51.7 & 33.3 & 6.7 & 40.0 & 5.0 & 0.0 & 5.0 \\
\hline 11 & $\mathrm{MS}$ & 23.3 & 12.3 & 0.3 & 5.2 & 41.2 & 55.0 & 2.2 & 57.2 & 0.5 & 0.0 & 0.5 \\
\hline 12 & MS & 21.7 & 25.0 & 1.7 & 18.3 & 66.7 & 24.7 & 8.5 & 33.2 & 0.0 & 0.0 & 0.0 \\
\hline 13 & MS & 13.7 & 1.8 & 1.7 & 6.2 & 23.3 & 73.3 & 0.0 & 73.3 & 0.0 & 0.0 & 0.0 \\
\hline 14 & MS & 27.4 & 2.2 & 0.0 & 7.0 & 36.6 & 63.3 & 0.0 & 63.3 & 0.0 & 0.0 & 0.0 \\
\hline 15 & LR & 19.0 & 43.3 & 0.3 & 24.7 & 87.3 & 12.3 & 0.0 & 12.3 & 0.3 & 0.0 & 0.3 \\
\hline 16 & LR & 17.0 & 33.3 & 0.0 & 23.7 & 74.0 & 26.0 & 0.0 & 26.0 & 0.0 & 0.0 & 0.0 \\
\hline 17 & LR & 16.7 & 28.3 & 0.0 & 6.7 & 51.7 & 43.3 & 3.0 & 46.3 & 0.3 & 0.0 & 0.3 \\
\hline 18 & LR & 10.0 & 30.0 & 0.0 & 31.7 & 71.7 & 26.0 & 2.0 & 28.0 & 0.0 & 0.0 & 0.0 \\
\hline 19 & LR & 8.0 & 8.3 & 0.0 & 32.0 & 48.3 & 48.3 & 0.0 & 48.3 & 3.3 & 0.0 & 3.3 \\
\hline 20 & LR & 28.7 & 10.0 & 0.0 & 5.3 & 44.0 & 47.0 & 9.0 & 56.0 & 0.0 & 0.0 & 0.0 \\
\hline 21 & LR & 15.0 & 11.3 & 0.0 & 18.7 & 45.0 & 52.7 & 2.3 & 55.0 & 0.0 & 0.0 & 0.0 \\
\hline 22 & LR & 19.0 & 20.8 & 0.2 & 1.7 & 41.7 & 58.3 & 0.0 & 58.3 & 0.0 & 0.0 & 0.0 \\
\hline
\end{tabular}




\begin{tabular}{|c|c|c|c|c|c|c|c|c|c|c|c|c|}
\hline 23 & LR & 37.3 & 9.7 & 0.0 & 12.7 & 59.7 & 13.3 & 0.3 & 13.7 & 0.0 & 0.0 & 0.0 \\
\hline 24 & LR & 23.7 & 11.7 & 0.0 & 9.3 & 44.7 & 55.0 & 0.3 & 55.3 & 0.0 & 0.0 & 0.0 \\
\hline 25 & ST & 17.3 & 13.3 & 0.0 & 10.3 & 41.0 & 57.3 & 1.3 & 58.7 & 0.0 & 0.0 & 0.0 \\
\hline 26 & ST & 11.7 & 12.7 & 3.3 & 3.7 & 31.3 & 66.7 & 0.3 & 67.0 & 0.0 & 0.0 & 0.0 \\
\hline 27 & ST & 15.0 & 20.0 & 0.0 & 60.0 & 95.0 & 3.3 & 1.0 & 4.3 & 0.0 & 0.0 & 0.0 \\
\hline 28 & ST & 5.0 & 14.3 & 0.3 & 9.3 & 29.0 & 70.0 & 0.3 & 70.3 & 0.3 & 0.0 & 0.3 \\
\hline 29 & ST & 30.0 & 23.3 & 0.0 & 20.0 & 73.3 & 23.3 & 3.3 & 26.7 & 0.0 & 0.0 & 0.0 \\
\hline 30 & ST & 13.5 & 9.5 & 0.0 & 14.8 & 37.8 & 61.7 & 0.0 & 61.7 & 0.2 & 0.0 & 0.2 \\
\hline 31 & TG & 33.3 & 23.3 & 0.0 & 36.3 & 93.0 & 3.7 & 0.0 & 3.7 & 3.3 & 0.0 & 3.3 \\
\hline 32 & TG & 38.3 & 0.0 & 0.0 & 60.0 & 98.3 & 0.0 & 1.7 & 1.7 & 0.0 & 0.0 & 0.0 \\
\hline 33 & TG & 26.8 & 0.0 & 0.0 & 46.7 & 73.5 & 25.0 & 1.3 & 26.3 & 0.0 & 0.0 & 0.0 \\
\hline 34 & TG & 33.3 & 30.3 & 0.0 & 35.7 & 99.3 & 0.7 & 0.0 & 0.7 & 0.0 & 0.0 & 0.0 \\
\hline 35 & TG & 15.0 & 3.7 & 0.0 & 53.3 & 72.0 & 0.0 & 11.3 & 11.3 & 16.7 & 0.0 & 16.7 \\
\hline 36 & TU & 16.0 & 0.0 & 0.7 & 2.9 & 19.6 & 75.0 & 5.3 & 80.3 & 0.1 & 0.0 & 0.1 \\
\hline 37 & TU & 16.7 & 0.0 & 0.0 & 36.7 & 53.3 & 45.3 & 0.7 & 46.0 & 0.0 & 0.0 & 0.0 \\
\hline 38 & TU & 10.7 & 0.0 & 0.0 & 0.0 & 10.7 & 26.0 & 0.3 & 26.3 & 0.0 & 62.7 & 62.7 \\
\hline 39 & TU & 19.3 & 0.0 & 0.0 & 0.0 & 19.3 & 33.3 & 2.3 & 35.7 & 0.0 & 45.0 & 45.0 \\
\hline 40 & TU & 28.2 & 0.0 & 0.0 & 10.7 & 38.8 & 54.7 & 3.3 & 58.0 & 0.0 & 2.3 & 2.3 \\
\hline 41 & TU & 16.7 & 0.0 & 0.0 & 50.0 & 66.7 & 33.3 & 0.0 & 33.3 & 0.0 & 0.0 & 0.0 \\
\hline 42 & TU & 44.0 & 0.0 & 0.0 & 37.7 & 81.7 & 18.3 & 0.0 & 18.3 & 0.0 & 0.0 & 0.0 \\
\hline 43 & $\mathrm{AL}$ & 26.0 & 0.0 & 0.0 & 56.7 & 82.7 & 16.7 & 0.7 & 17.3 & 0.0 & 0.0 & 0.0 \\
\hline 44 & $\mathrm{AL}$ & 10.0 & 0.0 & 0.0 & 51.7 & 61.7 & 31.7 & 5.0 & 36.7 & 0.0 & 0.0 & 0.0 \\
\hline 45 & $A L$ & 14.3 & 0.0 & 0.0 & 52.0 & 66.3 & 23.3 & 9.7 & 33.0 & 0.0 & 0.0 & 0.0 \\
\hline 46 & $\mathrm{AL}$ & 13.3 & 0.0 & 0.0 & 23.3 & 36.7 & 61.7 & 1.7 & 63.3 & 0.0 & 0.0 & 0.0 \\
\hline 47 & $\mathrm{AL}$ & 10.5 & 0.0 & 0.0 & 63.0 & 73.5 & 20.3 & 4.7 & 25.0 & 0.3 & 0.0 & 0.3 \\
\hline 48 & $A L$ & 8.0 & 0.0 & 0.0 & 76.7 & 84.7 & 13.3 & 2.0 & 15.3 & 0.0 & 0.0 & 0.0 \\
\hline
\end{tabular}




\begin{tabular}{|c|c|c|c|c|c|c|c|c|c|c|c|c|}
\hline 49 & $\mathrm{AL}$ & 21.0 & 0.0 & 0.0 & 46.7 & 67.7 & 31.7 & 0.3 & 32.0 & 0.0 & 0.0 & 0.0 \\
\hline 50 & $\mathrm{AL}$ & 15.0 & 0.0 & 0.0 & 61.3 & 76.3 & 23.3 & 0.0 & 23.3 & 0.0 & 0.0 & 0.0 \\
\hline 51 & $\mathrm{AL}$ & 26.7 & 0.0 & 0.0 & 46.7 & 73.3 & 26.7 & 0.0 & 26.7 & 0.0 & 0.0 & 0.0 \\
\hline 52 & WL & 13.7 & 0.0 & 0.0 & 56.7 & 70.3 & 29.7 & 0.0 & 29.7 & 0.0 & 0.0 & 0.0 \\
\hline 53 & WL & 13.3 & 0.0 & 0.0 & 58.3 & 71.7 & 28.3 & 0.0 & 28.3 & 0.0 & 0.0 & 0.0 \\
\hline 54 & WL & 0.0 & 0.0 & 0.0 & 65.7 & 65.7 & 30.0 & 1.0 & 31.0 & 0.0 & 0.0 & 0.0 \\
\hline 55 & WL & 10.0 & 0.0 & 0.0 & 52.7 & 62.7 & 36.7 & 0.0 & 36.7 & 0.0 & 0.0 & 0.0 \\
\hline 56 & WL & 10.3 & 0.0 & 0.0 & 43.3 & 53.7 & 43.7 & 2.7 & 46.3 & 0.0 & 0.0 & 0.0 \\
\hline 57 & YG & 4.0 & 0.3 & 0.0 & 25.7 & 30.0 & 68.3 & 1.7 & 70.0 & 0.0 & 0.0 & 0.0 \\
\hline 58 & YG & 11.3 & 0.0 & 0.0 & 53.3 & 64.7 & 30.0 & 5.3 & 35.3 & 0.0 & 0.0 & 0.0 \\
\hline 59 & YG & 8.3 & 0.0 & 0.0 & 81.7 & 90.0 & 8.2 & 1.7 & 9.8 & 0.0 & 0.0 & 0.0 \\
\hline 60 & YG & 15.0 & 0.0 & 0.0 & 60.0 & 75.0 & 6.7 & 6.7 & 13.3 & 0.0 & 0.0 & 0.0 \\
\hline 61 & YG & 13.3 & 3.3 & 0.0 & 15.7 & 32.3 & 66.0 & 1.7 & 67.7 & 0.0 & 0.0 & 0.0 \\
\hline 62 & YG & 8.3 & 1.7 & 0.0 & 41.7 & 51.7 & 46.7 & 1.7 & 48.3 & 0.0 & 0.0 & 0.0 \\
\hline 63 & YG & 18.3 & 1.7 & 0.0 & 30.0 & 50.0 & 46.7 & 3.3 & 50.0 & 0.0 & 0.0 & 0.0 \\
\hline 64 & YG & 13.7 & 0.0 & 0.0 & 53.3 & 67.0 & 28.3 & 4.7 & 33.0 & 0.0 & 0.0 & 0.0 \\
\hline 65 & YG & 8.3 & 0.0 & 0.0 & 43.3 & 51.7 & 43.3 & 5.0 & 48.3 & 0.0 & 0.0 & 0.0 \\
\hline 66 & PG & 16.7 & 0.0 & 0.0 & 26.7 & 43.3 & 56.7 & 0.0 & 56.7 & 0.0 & 0.0 & 0.0 \\
\hline 67 & PG & 13.3 & 0.0 & 0.0 & 66.7 & 80.0 & 16.7 & 3.3 & 20.0 & 0.0 & 0.0 & 0.0 \\
\hline 68 & PG & 10.0 & 0.0 & 1.7 & 80.0 & 91.7 & 3.3 & 5.0 & 8.3 & 0.0 & 0.0 & 0.0 \\
\hline 69 & LR & 2.3 & 20.7 & 0.0 & 9.3 & 32.3 & 66.0 & 1.0 & 67.0 & 0.0 & 0.0 & 0.0 \\
\hline 70 & LR & 14.0 & 19.3 & 0.0 & 35.7 & 69.0 & 29.7 & 0.3 & 30.0 & 0.0 & 0.0 & 0.0 \\
\hline 71 & LR & 3.3 & 38.3 & 0.0 & 58.3 & 100.0 & 0.0 & 0.0 & 0.0 & 0.0 & 0.0 & 0.0 \\
\hline 72 & LR & 9.0 & 23.3 & 0.0 & 61.0 & 93.3 & 6.7 & 0.0 & 6.7 & 0.0 & 0.0 & 0.0 \\
\hline 73 & LR & 15.0 & 18.3 & 0.0 & 40.0 & 73.3 & 26.7 & 0.0 & 26.7 & 0.0 & 0.0 & 0.0 \\
\hline 74 & LR & 19.3 & 6.7 & 0.0 & 20.0 & 46.0 & 54.0 & 0.0 & 54.0 & 0.0 & 0.0 & 0.0 \\
\hline
\end{tabular}




\begin{tabular}{|c|c|c|c|c|c|c|c|c|c|c|c|c|}
\hline 75 & LR & 0.0 & 13.3 & 0.0 & 56.7 & 70.0 & 6.7 & 23.3 & 30.0 & 0.0 & 0.0 & 0.0 \\
\hline 76 & LR & 6.7 & 10.0 & 0.0 & 23.3 & 40.0 & 60.0 & 0.0 & 60.0 & 0.0 & 0.0 & 0.0 \\
\hline 77 & LR & 13.3 & 0.0 & 0.0 & 50.0 & 63.3 & 32.7 & 4.0 & 36.7 & 0.0 & 0.0 & 0.0 \\
\hline 78 & LR & 3.3 & 6.7 & 0.0 & 5.0 & 15.0 & 81.7 & 0.0 & 81.7 & 0.0 & 0.0 & 0.0 \\
\hline 79 & LR & 10.2 & 6.7 & 0.0 & 9.8 & 26.7 & 73.3 & 0.0 & 73.3 & 0.0 & 0.0 & 0.0 \\
\hline 80 & MS & 6.8 & 6.7 & 0.0 & 5.0 & 18.5 & 76.5 & 1.7 & 78.2 & 0.0 & 0.0 & 0.0 \\
\hline 81 & MS & 8.3 & 3.3 & 0.2 & 25.0 & 36.8 & 46.5 & 16.7 & 63.2 & 0.0 & 0.0 & 0.0 \\
\hline 82 & MS & 8.3 & 28.3 & 0.0 & 24.7 & 61.3 & 36.7 & 2.0 & 38.7 & 0.0 & 0.0 & 0.0 \\
\hline 83 & MS & 3.3 & 3.3 & 0.0 & 15.0 & 21.7 & 78.3 & 0.0 & 78.3 & 0.0 & 0.0 & 0.0 \\
\hline 84 & MS & 5.0 & 10.0 & 0.0 & 23.3 & 38.3 & 56.7 & 5.0 & 61.7 & 0.0 & 0.0 & 0.0 \\
\hline 85 & MS & 23.3 & 0.0 & 0.0 & 16.7 & 40.0 & 51.7 & 5.0 & 56.7 & 0.0 & 0.0 & 0.0 \\
\hline 86 & MS & 18.3 & 0.0 & 0.0 & 31.7 & 50.0 & 48.3 & 1.7 & 50.0 & 0.0 & 0.0 & 0.0 \\
\hline 87 & ST & 4.3 & 0.0 & 26.0 & 21.7 & 52.0 & 48.0 & 0.0 & 48.0 & 0.0 & 0.0 & 0.0 \\
\hline 88 & ST & 24.8 & 23.2 & 0.0 & 31.7 & 79.7 & 20.0 & 0.3 & 20.3 & 0.0 & 0.0 & 0.0 \\
\hline 89 & ST & 5.0 & 37.7 & 0.0 & 8.7 & 51.3 & 48.3 & 0.3 & 48.7 & 0.0 & 0.0 & 0.0 \\
\hline 90 & ST & 25.0 & 28.0 & 0.3 & 10.0 & 63.3 & 36.7 & 0.0 & 36.7 & 0.0 & 0.0 & 0.0 \\
\hline 91 & ST & 22.3 & 16.7 & 0.0 & 34.3 & 73.3 & 26.7 & 0.0 & 26.7 & 0.0 & 0.0 & 0.0 \\
\hline 92 & ST & 27.7 & 20.0 & 0.0 & 14.7 & 62.3 & 37.3 & 0.3 & 37.7 & 0.0 & 0.0 & 0.0 \\
\hline 93 & ST & 26.7 & 23.3 & 0.0 & 14.7 & 64.7 & 35.0 & 0.3 & 35.3 & 0.0 & 0.0 & 0.0 \\
\hline 94 & TU & 25.0 & 17.3 & 0.3 & 10.3 & 53.0 & 45.0 & 2.0 & 47.0 & 0.0 & 0.0 & 0.0 \\
\hline 95 & TU & 41.3 & 5.0 & 8.0 & 4.7 & 59.0 & 39.3 & 1.7 & 41.0 & 0.0 & 0.0 & 0.0 \\
\hline 96 & TU & 12.3 & 13.3 & 0.0 & 0.0 & 25.7 & 53.3 & 21.0 & 74.3 & 0.0 & 0.0 & 0.0 \\
\hline 97 & TU & 31.0 & 18.3 & 3.7 & 10.0 & 63.0 & 35.0 & 2.0 & 37.0 & 0.0 & 0.0 & 0.0 \\
\hline 98 & TU & 26.0 & 26.7 & 0.0 & 10.0 & 62.7 & 37.3 & 0.0 & 37.3 & 0.0 & 0.0 & 0.0 \\
\hline 99 & TU & 6.7 & 40.0 & 0.0 & 10.0 & 56.7 & 43.3 & 0.0 & 43.3 & 0.0 & 0.0 & 0.0 \\
\hline 100 & TU & 7.7 & 30.0 & 0.0 & 10.0 & 47.7 & 51.7 & 0.0 & 51.7 & 0.0 & 0.0 & 0.0 \\
\hline
\end{tabular}




\begin{tabular}{|c|c|c|c|c|c|c|c|c|c|c|c|c|}
\hline 101 & TU & 3.0 & 46.3 & 0.0 & 2.7 & 52.0 & 47.3 & 0.0 & 47.3 & 0.0 & 0.0 & 0.0 \\
\hline 102 & $\mathrm{WL}$ & 2.0 & 38.0 & 0.0 & 3.3 & 43.3 & 56.7 & 0.0 & 56.7 & 0.0 & 0.0 & 0.0 \\
\hline 103 & WL & 13.3 & 53.3 & 1.7 & 10.0 & 78.3 & 21.7 & 0.0 & 21.7 & 0.0 & 0.0 & 0.0 \\
\hline 104 & WL & 16.7 & 43.3 & 0.0 & 15.0 & 75.0 & 5.0 & 20.0 & 25.0 & 0.0 & 0.0 & 0.0 \\
\hline 105 & $\mathrm{WL}$ & 20.0 & 25.0 & $\begin{array}{l}16.7 \\
\end{array}$ & $\begin{array}{ll}16.7 \\
\end{array}$ & 78.3 & 21.7 & 0.0 & 21.7 & 0.0 & 0.0 & 0.0 \\
\hline 106 & OU & 15.0 & 25.0 & 6.7 & 21.7 & 68.3 & 31.7 & 0.0 & 31.7 & 0.0 & 0.0 & 0.0 \\
\hline 107 & OU & 17.0 & 11.7 & 0.0 & 8.0 & 36.7 & 53.3 & 10.0 & 63.3 & 0.0 & 0.0 & 0.0 \\
\hline 108 & OU & 13.3 & 33.3 & 0.0 & 20.0 & 66.7 & 33.3 & 0.0 & 33.3 & 0.0 & 0.0 & 0.0 \\
\hline 109 & OU & 7.3 & 28.3 & 0.0 & 5.0 & 40.7 & 53.3 & 6.0 & 59.3 & 0.0 & 0.0 & 0.0 \\
\hline 110 & YG & 19.0 & 15.0 & 0.0 & 24.3 & 58.3 & 38.3 & 3.3 & 41.7 & 0.0 & 0.0 & 0.0 \\
\hline 111 & YG & 10.0 & 21.7 & 0.0 & 1.7 & 33.3 & 66.7 & 0.0 & 66.7 & 0.0 & 0.0 & 0.0 \\
\hline 112 & YG & 10.0 & 23.3 & 0.0 & 5.0 & 38.3 & 60.0 & 1.7 & 61.7 & 0.0 & 0.0 & 0.0 \\
\hline
\end{tabular}




\begin{tabular}{|c|c|c|c|c|}
\hline $\begin{array}{l}\text { Total } \\
\text { sample }\end{array}$ & $\begin{array}{l}\text { Focal } \\
\text { subject }\end{array}$ & $\begin{array}{l}\text { Frugivory } \\
\text { (\%) }\end{array}$ & $\begin{array}{l}\text { Folivory } \\
(\%)\end{array}$ & $\begin{array}{l}\text { Faunivory } \\
(\%)\end{array}$ \\
\hline 1 & MS & 34.0 & 49.3 & 0.0 \\
\hline 2 & LR & 92.5 & 5.0 & 0.0 \\
\hline 3 & $W L$ & 38.3 & 26.7 & 0.0 \\
\hline 4 & YG & 60.0 & 36.7 & 0.0 \\
\hline 5 & LR & 40.0 & 50.0 & 10.0 \\
\hline 6 & MS & 80.0 & 0.0 & 20.0 \\
\hline 7 & MS & 63.3 & 29.7 & 0.3 \\
\hline 8 & MS & 69.3 & 30.7 & 0.0 \\
\hline 9 & MS & 23.4 & 76.3 & 0.2 \\
\hline 10 & MS & 51.7 & 40.0 & 5.0 \\
\hline 11 & MS & 41.2 & 57.2 & 0.5 \\
\hline 12 & MS & 66.7 & 33.2 & 0.0 \\
\hline 13 & MS & 23.3 & 73.3 & 0.0 \\
\hline 14 & MS & 36.6 & 63.3 & 0.0 \\
\hline 15 & LR & 87.3 & 12.3 & 0.3 \\
\hline 16 & LR & 74.0 & 26.0 & 0.0 \\
\hline 17 & LR & 51.7 & 46.3 & 0.3 \\
\hline 18 & LR & 71.7 & 28.0 & 0.0 \\
\hline 19 & LR & 48.3 & 48.3 & 3.3 \\
\hline 20 & LR & 44.0 & 56.0 & 0.0 \\
\hline 21 & LR & 45.0 & 55.0 & 0.0 \\
\hline 22 & LR & 41.7 & 58.3 & 0.0 \\
\hline 23 & LR & 59.7 & 13.7 & 0.0 \\
\hline 24 & LR & 44.7 & 55.3 & 0.0 \\
\hline
\end{tabular}




\begin{tabular}{|c|c|c|c|c|}
\hline 25 & ST & 41.0 & 58.7 & 0.0 \\
\hline 26 & ST & 31.3 & 67.0 & 0.0 \\
\hline 27 & ST & 95.0 & 4.3 & 0.0 \\
\hline 28 & ST & 29.0 & 70.3 & 0.3 \\
\hline 29 & ST & 73.3 & 26.7 & 0.0 \\
\hline 30 & ST & 37.8 & 61.7 & 0.2 \\
\hline 31 & TG & 93.0 & 3.7 & 3.3 \\
\hline 32 & TG & 98.3 & 1.7 & 0.0 \\
\hline 33 & TG & 73.5 & 26.3 & 0.0 \\
\hline 34 & TG & 99.3 & 0.7 & 0.0 \\
\hline 35 & TG & 72.0 & 11.3 & 16.7 \\
\hline 36 & TU & 19.6 & 80.3 & 0.1 \\
\hline 37 & TU & 53.3 & 46.0 & 0.0 \\
\hline 38 & TU & 10.7 & 26.3 & 62.7 \\
\hline 39 & TU & 19.3 & 35.7 & 45.0 \\
\hline 40 & TU & 38.8 & 58.0 & 2.3 \\
\hline 41 & TU & 66.7 & 33.3 & 0.0 \\
\hline 42 & TU & 81.7 & 18.3 & 0.0 \\
\hline 43 & $A L$ & 82.7 & 17.3 & 0.0 \\
\hline 44 & $\mathrm{AL}$ & 61.7 & 36.7 & 0.0 \\
\hline 45 & $A L$ & 66.3 & 33.0 & 0.0 \\
\hline 46 & $A L$ & 36.7 & 63.3 & 0.0 \\
\hline 47 & $\mathrm{AL}$ & 73.5 & 25.0 & 0.3 \\
\hline 48 & $\mathrm{AL}$ & 84.7 & 15.3 & 0.0 \\
\hline 49 & $A L$ & 67.7 & 32.0 & 0.0 \\
\hline 50 & $\mathrm{AL}$ & 76.3 & 23.3 & 0.0 \\
\hline
\end{tabular}




\begin{tabular}{|c|c|c|c|c|}
\hline 51 & $\mathrm{AL}$ & 73.3 & 26.7 & 0.0 \\
\hline 52 & $W L$ & 70.3 & 29.7 & 0.0 \\
\hline 53 & WL & 71.7 & 28.3 & 0.0 \\
\hline 54 & WL & 65.7 & 31.0 & 0.0 \\
\hline 55 & $W L$ & 62.7 & 36.7 & 0.0 \\
\hline 56 & $W L$ & 53.7 & 46.3 & 0.0 \\
\hline 57 & YG & 30.0 & 70.0 & 0.0 \\
\hline 58 & YG & 64.7 & 35.3 & 0.0 \\
\hline 59 & YG & 90.0 & 9.8 & 0.0 \\
\hline 60 & YG & 75.0 & 13.3 & 0.0 \\
\hline 61 & YG & 32.3 & 67.7 & 0.0 \\
\hline 62 & YG & 51.7 & 48.3 & 0.0 \\
\hline 63 & YG & 50.0 & 50.0 & 0.0 \\
\hline 64 & YG & 67.0 & 33.0 & 0.0 \\
\hline 65 & YG & 51.7 & 48.3 & 0.0 \\
\hline 66 & PG & 43.3 & 56.7 & 0.0 \\
\hline 67 & PG & 80.0 & 20.0 & 0.0 \\
\hline 68 & PG & 91.7 & 8.3 & 0.0 \\
\hline 69 & LR & 32.3 & 67.0 & 0.0 \\
\hline 70 & LR & 69.0 & 30.0 & 0.0 \\
\hline 71 & LR & 100.0 & 0.0 & 0.0 \\
\hline 72 & LR & 93.3 & 6.7 & 0.0 \\
\hline 73 & LR & 73.3 & 26.7 & 0.0 \\
\hline 74 & LR & 46.0 & 54.0 & 0.0 \\
\hline 75 & LR & 70.0 & 30.0 & 0.0 \\
\hline 76 & LR & 40.0 & 60.0 & 0.0 \\
\hline
\end{tabular}




\begin{tabular}{|r|l|l|l|l|}
\hline 77 & LR & 63.3 & 36.7 & 0.0 \\
\hline 78 & LR & 15.0 & 81.7 & 0.0 \\
\hline 79 & LR & 26.7 & 73.3 & 0.0 \\
\hline 80 & MS & 18.5 & 78.2 & 0.0 \\
\hline 81 & MS & 36.8 & 63.2 & 0.0 \\
\hline 82 & MS & 61.3 & 38.7 & 0.0 \\
\hline 83 & MS & 21.7 & 78.3 & 0.0 \\
\hline 84 & MS & 38.3 & 61.7 & 0.0 \\
\hline 85 & MS & 40.0 & 56.7 & 0.0 \\
\hline 86 & MS & 50.0 & 50.0 & 0.0 \\
\hline 87 & ST & 52.0 & 48.0 & 0.0 \\
\hline 88 & ST & 79.7 & 20.3 & 0.0 \\
\hline 89 & ST & 51.3 & 48.7 & 0.0 \\
\hline 90 & ST & 63.3 & 36.7 & 0.0 \\
\hline 91 & ST & 73.3 & 26.7 & 0.0 \\
\hline 92 & ST & 62.3 & 37.7 & 0.0 \\
\hline 93 & ST & 64.7 & 35.3 & 0.0 \\
\hline 94 & TU & 53.0 & 47.0 & 0.0 \\
\hline 95 & TU & 59.0 & 41.0 & 0.0 \\
\hline 96 & TU & 25.7 & 74.3 & 0.0 \\
\hline 97 & TU & 63.0 & 37.0 & 0.0 \\
\hline 98 & TU & 56.7 & 43.3 & 0.0 \\
\hline 99 & TU & 52.0 & 47.3 & 0.0 \\
\hline 100 & TU & & & 0.0 \\
\hline 101 & TU & WL & 51.7 & 0.0 \\
\hline & & & & \\
\hline 102 & & 56.7 & 0.0 & 0.0 \\
\hline
\end{tabular}




\begin{tabular}{|r|l|r|r|r|}
\hline 103 & WL & 78.3 & 21.7 & 0.0 \\
\hline 104 & WL & 75.0 & 25.0 & 0.0 \\
\hline 105 & WL & 78.3 & 21.7 & 0.0 \\
\hline 106 & OU & 68.3 & 31.7 & 0.0 \\
\hline 107 & OU & 36.7 & 63.3 & 0.0 \\
\hline 108 & OU & 66.7 & 33.3 & 0.0 \\
\hline 109 & OU & 40.7 & 59.3 & 0.0 \\
\hline 110 & YG & 58.3 & 41.7 & 0.0 \\
\hline 111 & YG & 33.3 & 66.7 & 0.0 \\
\hline 112 & YG & 38.3 & 61.7 & 0.0 \\
\hline
\end{tabular}

